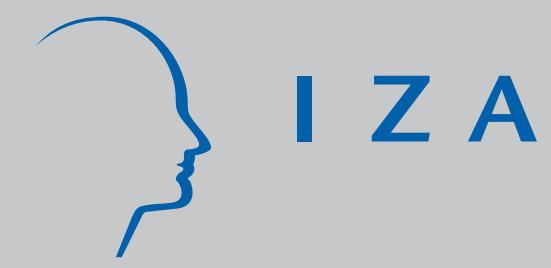

IZA DP No. 460

Family Matters: The Role of the Family in Immigrants' Destination Language Acquisition

Barry R. Chiswick

Yew Liang Lee

Paul W. Miller

March 2002 


\title{
Family Matters: The Role of the Family in Immigrants' Destination Language Acquisition
}

\author{
Barry R. Chiswick \\ University of Illinois, Chicago and IZA, Bonn \\ Yew Liang Lee \\ University of Western Australia \\ Paul W. Miller \\ University of Western Australia
}

Discussion Paper No. 460

March 2002

\author{
IZA \\ P.O. Box 7240 \\ D-53072 Bonn \\ Germany \\ Tel.: +49-228-3894-0 \\ Fax: +49-228-3894-210 \\ Email: iza@iza.org
}

This Discussion Paper is issued within the framework of IZA's research area Internationalization of Labor Markets. Any opinions expressed here are those of the author(s) and not those of the institute. Research disseminated by IZA may include views on policy, but the institute itself takes no institutional policy positions.

The Institute for the Study of Labor (IZA) in Bonn is a local and virtual international research center and a place of communication between science, politics and business. IZA is an independent, nonprofit limited liability company (Gesellschaft mit beschränkter Haftung) supported by the Deutsche Post AG. The center is associated with the University of Bonn and offers a stimulating research environment through its research networks, research support, and visitors and doctoral programs. IZA engages in (i) original and internationally competitive research in all fields of labor economics, (ii) development of policy concepts, and (iii) dissemination of research results and concepts to the interested public. The current research program deals with (1) mobility and flexibility of labor, (2) internationalization of labor markets, (3) the welfare state and labor markets, (4) labor markets in transition countries, (5) the future of labor, (6) evaluation of labor market policies and projects and (7) general labor economics.

IZA Discussion Papers often represent preliminary work and are circulated to encourage discussion. Citation of such a paper should account for its provisional character. A revised version may be available on the IZA website (www.iza.org) or directly from the author. 
IZA Discussion Paper No. 460

March 2002

\section{ABSTRACT \\ Family Matters: The Role of the Family in Immigrants' Destination Language Acquisition*}

This paper is concerned with the relationship among family members in the determinants of destination language proficiency among immigrants. A model of immigrant language proficiency is augmented to include dynamics among family members. It is tested using data on a sample of recent immigrants. Children are shown to have a negative effect on their mother's language proficiency, but no effect on their father's. There is a substantial positive correlation between the language skills of spouses. This is due to the correlation between spouses in both the measured determinants and the unmeasured determinants of destination language skills among spouses.

JEL Classification: J15, J16, J24, J61

Keywords: Immigrants, language skills, family, longitudinal data

Barry R. Chiswick

Department of Economics (MC 144)

College of Business Administration

601 S. Morgan Street (Room 2103 UH)

Chicago, IL 60607-7121

USA

Tel.: +1 (312) 9962683

Fax: +1 (312) 9963344

Email: brchis@uic.edu

\footnotetext{
* Miller acknowledges financial assistance from the Australian Research Council.
} 


\section{INTRODUCTION}

Some immigrants are single and make their migration decisions without having family in the intended destination. The majority of immigrants, however, move with family members and/or make decisions with reference to family in the destination country. As the decision to move is made on this basis, it is possible that other major decisions of immigrants will be influenced by family members, either those who are part of the migrating unit, or part of the community in which the immigrant is settling. This has been increasingly recognised in research into the economic progress of immigrants. The importance of being married to a foreign national, for example, has been shown in studies of dominant language fluency (e.g., Chiswick and Miller (1992)). Baker and Benjamin (1997) have modelled immigrant labour supply within a family investment model, while Chiswick (1977)(1988) and Borjas (1992) have examined in a family context the rate of intergenerational mobility between immigrants and their children. A major conclusion that can be drawn from these studies is that the family matters in studies of immigrant adjustment. That family matters is not surprising given that migration decisions are influenced by intending immigrants' family members (Mincer (1978)) and by the use of family relations in the destination in the issuance of at least some visas in most receiving countries.

This study extends this important line of research by investigating the dominant language skill development of spouses within migrating units in Australia. It analyzes the proficiency in English of a sample of Principal Applicant (PAs) immigrants in Australia, that is, immigrants upon whom the approval to immigrate was based, and of the spouses who were part of the application to migrate made by these PAs. This latter group of immigrants are referred to in this study as Migrating Unit Spouses (MUSs). An assessment is made of whether the observed factors that influence dominant language acquisition, such as educational attainment and age at migration, are the same for PAs and MUSs. It also examines the role that correlation among unobserved factors for both spouses play in the development of language skills of spouses within migrating units. 
The structure of the paper is as follows. Section II presents a model of dominant language skills for the individual and outlines how the method of estimation can be modified for the study of language skills within the migrating unit. The data base, comprising administrative records on visa category and wave one of the Longitudinal Survey of Immigrants to Australia, is described in Section III. Section IV examines the relationships between the English skills of the PA and spouse for the approximately one-third of migrating units where a spouse migrated with (accompanied) the PA. Regression results of the model of dominant language skills for the family are presented and discussed in Section V. Concluding comments are provided in Section VI.

\section{A MODEL OF LANGUAGE SKILLS}

The acquisition of dominant language proficiency among immigrants has generally been modelled from a human capital perspective (see, for example, Breton (1978a)(1978b), Chiswick and Miller (1992)(1995)(1998)). Three broad sets of factors are postulated as determinants of language attainment: economic incentives, efficiency in language acquisition, and exposure to the dominant language prior to and after migration. ${ }^{1}$ That is, an immigrant's fluency in the dominant language (LANG) may be modelled as:

$$
\mathrm{LANG}=\mathrm{f}(\text { economic incentives, efficiency, exposure }) .
$$

Economic incentives for the acquisition of language skills depend on the labor market (i.e., the wage, training and employment increments) and consumption (i.e., lower search costs for favorable prices and higher quality goods and services) benefits expected to be associated with dominant language proficiency, and the length of time over which these benefits are expected to accrue. Some of these benefits are expected to be more important for PAs than for MUSs. For example, among economic immigrants and those issued visas based on their labor market status, given their primary role in the migration application process, the links between labor market

\footnotetext{
${ }^{1}$ This approach has been used in empirical studies of English-language skills among immigrants in the United States (Chiswick and Miller (1992)(1998)) and Australia (Chiswick and Miller (1995)(1996)(1999)), Hebrew-language skills in Israel (Beenstock (1996); Chiswick (1998)), Frenchand English-language skills among immigrants in Canada (Chiswick and Miller (1992)(1994a)(2001)) and language skills among immigrants in Germany (Dustmann (1994)). The model is highly robust across destination countries, time periods, countries of origin and legal status.
} 
benefits and language skills should be stronger for PAs than for MUSs. In comparison, the links between consumption benefits and language skills should be relatively stronger for MUSs than for PAs. The absence of suitable measures of the expected increments in labor market and consumption benefits on an individual basis means that these factors have to be treated as unobservables in this study. The relationship between these and other unobservables in the models of English-speaking proficiency for PAs and MUSs can, however, be examined within the context of the model of family language skills outlined below.

The expected length of time over which the wage and other employment and consumption gains are to be realized is also likely to be an important factor. Information on whether immigrants expected to leave Australia permanently at some future date can be used to capture this set of effects. Birthplace can also be used as a measure of the incidence of return migration, since origins differ in the extent of permanent and sojourner migration. Finally, the geographic distance of the country of origin from the destination is also relevant here as greater geographic distance is expected to be associated with more favorable selectivity in immigration and with a lesser expectation of return migration, and hence result in a greater incentive to invest in destination specific skills, including language skills (see Chiswick and Miller (1998)).

Efficiency refers to the extent to which a given amount of destination language exposure produces language proficiency. It has been shown in numerous studies that proficiency is enhanced by a higher level of education and by migration while young (see Long (1990), Service and Craik (1993) on the age effects in language attainment). In comparison to the literature, the age at migration effects may have a different interpretation in this analysis, as there may not have been sufficient time in Australia (only 5 to 6 months) among the sample of recent arrivals for the age (at migration) variable to reflect the impact of the speed at which English can be learned after migration. A second factor that the age variable may reflect is the learning of English at school among younger cohorts of immigrants. In the absence of substantial complementarities with other factors not included in the analysis, and which differ appreciably between PAs and MUSs, both education and age at migration should exercise similar effects on the language skills of PAs and MUSs. However, as the PA 
was the person who made the application to migrate, and the MUS was a tied mover, the two samples could differ in important ways, such as commitment to the labor market and success in Australia. ${ }^{2}$ If such differences are important then the impacts of the efficiency variables may differ between PAs and MUSs.

Efficiency will depend, in part, on "linguistic distance", that is, the extent of the difference between the origin and destination language. The greater the linguistic difference between the destination and the origin language, the lower would be the efficiency of an immigrant for learning the destination language. Linguistic distance should have similar impacts on the rates of English proficiency of PAs and MUSs.

An index of "linguistic distance" based on the degree of difficulty that Americans who are native English speakers have learning foreign languages has been developed by Chiswick and Miller (1998). It is derived from a set of language learning scores (LS) presented in Hart-Gonzalez and Lindemann (1993). A low value of the score is indicative of a high degree of difficulty (e.g., Cantonese LS $=1.25$ ) and a high value is indicative of a low degree of difficulty (e.g., Dutch LS $=2.75$ ). In the empirical application, linguistic distance is measured as the reciprocal of the language score, that is, $\mathrm{LD}=1 / \mathrm{LS}$. Thus, a higher value for LD means a greater distance between English and the origin language.

Exposure has three dimensions. These are: exposure prior to migration, time units of exposure in the destination country ${ }^{3}$, and the intensity of exposure per unit of time in the destination. Several measures of exposure prior to migration are considered in this study. The first of these is constructed from information on the self-reported extent of the immigrant's contact with people from different countries (not necessarily Australia) and cultures in the country of origin. The hypothesis is that immigrants,

\footnotetext{
${ }^{2}$ In practice the PA could simply be the family member with the greater number of points in one of the points-tested categories or simply the lowest cost of obtaining a visa rather than the primary immigrant in the family. The implications of this possibility cannot be tested. It is known though that in 80 percent of cases it was self-reported that the PA was the prime decision maker or joint decision maker with their spouse.

${ }^{3}$ The number of years since migration provides a measure of time units of exposure in the destination country. While this variable plays a key role in cross-sectional studies, it is not a direct consideration in the study of language skills in a single arrival cohort since duration is the same for all observations.
} 
both PAs and MUSs, from countries where there is a lot of contact of this nature would be more likely to have been exposed to English, or at least have a relatively favorable disposition towards other cultures that may be associated with a greater preparedness to learn English.

A second variable is whether the immigrant visited Australia at least once prior to migrating. Visits to Australia prior to migration could reflect two factors. On the one hand, the immigrant would be exposed to English during such visits. On the other hand, the visits could be indicative of a greater degree of planning for the migration and hence a greater attention to the language skills required in the destination. This would reduce expected emigration. ${ }^{4}$ Accordingly, it is expected that immigrants who visited Australia prior to migrating would have English skills superior to the skills of those who did not visit Australia. While this should hold for any immigrant-receiving country, it should be particularly relevant for immigrants in Australia, given the distances (high cost) involved in international travel. Information on visits to Australia prior to migration is only available for the PA, and it is not known if the MUS visited Australia. While the variable constructed for the PA can be used for the MUS, if only on the grounds that the MUS uses information on Australia from the PA's visit, there will be measurement error associated with it that will attenuate the estimated impact. Hence, it is expected that this variable will have greater effect on the language skills of PAs than on the skills of MUSs. ${ }^{5}$

The intensity of exposure per unit of time in the destination is more complex. It will depend on the characteristics of the person's family and location in Australia. The home environment is measured in most analyses through variables for the number and ages of children, and for the birthplace or language skills of the spouse. In the LSIA there is information both on the family structure and on whether any children live

\footnotetext{
${ }^{4}$ Return migration rates vary considerable in Australia, and these variations appear to be related to social and geographic distance. In 1990-91 there were 12,627 permanent departees from Australia who were not born in either Australia or New Zealand, representing around 3.4 departees per 1000 foreign born (other than from New Zealand) in Australia. The emigration rates are high for the UK and Ireland (4.8 per 1000), low for the rest of Europe (e.g., 1.1 for Italy, 2.1 for Germany), around 3 for the Middle East and North Africa, South East Asia and North East Asia, and 5.1 for South and Central America and the Caribbean (calculations based on DIMA (1999)).

${ }^{5}$ Data were collected in the survey on the length of the last visit to Australia, but not on the total length of time spent in Australia on all visits.
} 
with their parents. Moreover, the survey contains details on whether other people who were part of the "migrating unit" live with the respondent. The following dichotomous variables may be included in the analysis: ${ }^{6}$ whether there are any children in the household (KIDS); whether other relatives who gained approval to migrate to Australia as part of the PA's migration application are present in the household (MUR); whether other relatives are present in the household (OR). Following Chiswick and Miller (1994b), it is expected that any adverse impact that children and other migrating unit members have on dominant language skills will be more intense for MUS than for PAs.

The information on the immigrant's living arrangements can be complemented with information on the main reason the immigrant chose his/her State of initial (wave one) settlement. Where "family/friends" is the main reason for the choice of location, it is expected that the immigrant will have access to an ethnic network. The availability of this ethnic network can reduce the exposure to, and practice in using, English in consumption and in labor market activities.

The characteristics of the person's location have typically been captured by a "minority-language concentration" variable. This is generally measured as the percentage of individuals living in the immigrant's region of residence that speaks the same minority language or has the same minority language mother tongue as the immigrant. A similar variable can be constructed using the birthplace characteristics of the immigrants in the region of residence, and this is the approach followed in this study. As there are obvious links between birthplace and language, especially when disaggregated birthplace data are used (around 50 birthplaces are used in the current analysis), this should not be viewed as a limitation. ${ }^{7}$

In a region where a high percentage of individuals are from the same birthplace, and hence many will speak the same minority language as the immigrant, the costs of not knowing the dominant language, or the benefits of learning the dominant language,

\footnotetext{
${ }^{6}$ Information on whether a spouse is present cannot be included in the model, as the analysis is restricted to PAs with a Migrating Unit spouse present at the time of the wave one interview.

${ }^{7}$ Where individuals do not report speaking a language other than English, a minority language concentration variable is often constructed using details on place of birth, adding to the similarity of the two variables.
} 
are presumably decreased. These effects arise from the ability to communicate in consumer, labor market and social activities in the immigrant's mother tongue. Moreover, since second language skills improve with experience using the language, improvements in English language skills are retarded by using the mother tongue.

Whether the effect of living among relatively high concentrations of compatriots who speak the immigrant's minority language is greater for PAs than for MUSs depends on whether the labor market factors that the variable captures are more important than the influences of consumer and social activities. If the labor market effects are more important then the effects of living in a region where a high percentage of individuals speak the same minority language, the effect of the concentration measure is expected to be stronger for PAs than for MUSs, who are more likely to be secondary labor market participants. ${ }^{8}$ Conversely, if consumer and social activities dominate in this regard, the effects of the birthplace concentration measure are likely to be stronger for MUSs than for PAs. ${ }^{9}$

The empirical counterpart to equation (1) used in this research is:

(2) $\quad$ LANG $=f($ visa category, age, education, gender, birthplace, preparation for migration, expected duration in destination, family structure, prevalence of origin language in region of residence, linguistic distance, georgrphic distance of origin country).

Probit regressions are used to estimate the model of language proficiency developed above. Thus, the probability that individual i will be proficient in English at wave one is given by:

$$
\begin{aligned}
& \operatorname{Pr}\left(L A N G_{i}^{P A}=1\right)=\Phi\left(\beta^{P A} X_{i}^{P A}\right) \\
& \operatorname{Pr}\left(L A N G_{i}^{M U S}=1\right)=\Phi\left(\beta^{M U S} X_{i}^{M U S}\right)
\end{aligned}
$$

\footnotetext{
${ }^{8}$ At the time of the wave one interviews, 29.5 percent of the PAs were employed in contrast to the 12.2 percent of the MUSs.

${ }^{9}$ It has been shown for Australia that the minority-language concentration measure reflects interactions in the marriage market, the presence of family members (beyond a spouse and children), and the availability of print and electronic media in the origin language, and hence with formal ethnic networks (Chiswick and Miller (1996)).
} 
where $L A N G_{i}=1$ for immigrants who are proficient in English, and is equal to 0 otherwise, $\Phi$ is the standard normal cumulative distribution function, $\beta$ is the parameters of the language proficiency model, $X$ is the set of explanatory variables and the superscripts $P A$ and MUS denote Principal Applicant and Migrating Unit Spouse, respectively.

When the family unit is considered, the joint probability of the PA and their MUS being proficient in English is of particular interest. This joint probability can be obtained by estimating the bivariate probit model represented by:

$$
\operatorname{Pr}\left(L A N G_{i}^{P A}=1, L A N G_{i}^{M U S}=1\right)=F\left(\beta^{P A} X_{i}^{P A}, \beta^{M U S} X_{i}^{M U S}, \rho\right)
$$

where $\mathrm{F}$ is the cumulative standard bivariate normal and $\rho$ denotes the correlation between the disturbances in the estimating equations for PAs and MUSs. The coefficients in the models of language skills for PAs and MUSs are allowed to differ in this model.

The interpretation of $\rho$ is that it captures the correlation between the effects of unobservables in the models of language skills of the partners. Consider a household where the PA was relatively highly motivated towards success in Australia and hence had a relatively high propensity to learn English. Under assortative mating, this implies similar characteristics for the spouse. As motivation is not a measured variable in this analysis, its influence will be captured via the error terms in the estimating equations for both PAs and MUSs, and a positive correlation between the error terms for partners would therefore be expected. Alternatively, a model where comparative advantage leads to specialization might see above average English skills of the PA being associated with below average English skills of the MUS, measured variables held constant, and a negative correlation between the disturbance terms in the equations. One spouse may then serve as the translator for the other.

The other possible combinations of language skills of the partners in a household can also be readily determined within the bivariate probit model. For example, the probability of the PA being proficient in English and the MUS having limited English 
skills is given by $\operatorname{Pr}\left(L A N G_{i}^{P A}=1, L A N G_{i}^{M U S}=0\right)=F\left(\beta^{P A} X_{i}^{P A},-\beta^{M U S} X_{i}^{M U S},-\rho\right)$. The probability of both partners having limited English skills is given by $\operatorname{Pr}\left(L A N G_{i}^{P A}=0, L A N G_{i}^{M U S}=0\right)=F\left(-\beta^{P A} X_{i}^{P A},-\beta^{M U S} X_{i}^{M U S}, \rho\right)$.

Estimates of single equation probit models for the PAs and their MUSs (separately), as well as of the bivariate probit model of the language skills of both family members, are obtained from the Longitudinal Survey of Immigrants to Australia.

\section{THE LONGITUDINAL SURVEY OF IMMIGRANTS TO AUSTRALIA}

The Longitudinal Survey of Immigrants to Australia is a longitudinal study of recently arrived offshore visaed immigrants (see Cobb-Clark (2001)). The population represented in the sample is all PAs, aged 15 years and over, who arrived in Australia in the two-year period of September 1993 to August 1995. ${ }^{10}$ The analyses of language skills development within the family unit in this paper are based only on the information collected during the first wave of interviews conducted at 5 to 6 months after migration. $^{11}$

Principal Applicant immigrants selected for interview were those who settled in State and Territory capital cities (including major urban centres close to capital cities such as Newcastle and Wollongong) as well as Cairns. Only 4 to 5 percent of the total of PA immigrants are excluded from the coverage of the survey because they live outside of these areas.

The final LSIA sample was 5192 PA arrivals. This represents about seven percent of all PAs who arrived in the two-year survey period. The population from which the sample was selected at random was stratified according to visa eligibility category ${ }^{12}$ and also by about fifty regions or countries of birth. Information was also collected,

\footnotetext{
10 The PA is the person upon whom the approval to immigrate was based. Excluded from the scope of the survey are New Zealand citizens and those granted a visa while resident in Australia. Information on visa category is obtained from administrative records.

11 Analyses that use information from all three waves are presented in Chiswick, Lee and Miller $(2002 a)(2002 b)$.

${ }^{12}$ The five main visa categories are Preferential Family, Concessional Family, Business Skills and Employer Nomination, Independent, and Humanitarian.
} 
by way of personal interview, from spouses present in the household who were part of the PA's migrating unit. In the first wave of interviews, 1769 spouses were interviewed.

The analyses presented below are restricted to PA immigrants between 15 and 64 years, excluding those from English speaking developed countries. These are the groups for whom the human capital model of dominant language acquisition outlined above will be most relevant. These restrictions are applied to the MUS also. A sample of 1081 family units (i.e., 1081 couples who received permission to migrate to Australia as part of the one application) is obtained. The definitions of the variables are presented in Appendix A. This Appendix also contains means and standard deviations of the variables.

A feature of the sampling frame for the LSIA is that PAs in smaller States and Territories were over-sampled. Weights are available to adjust for this. As noted by Murphy (1997, p.66), the LSIA data should be used in weighted form so that the sample reflects the total population of immigrants arriving in the reference period. All analyses in this study use relevant estimation weights. Experiments show that the use of weights has a reasonably modest effect on the statistical results.

The LSIA-wave one contains a considerable amount of information on language skills. Individuals were required to provide details on the languages they speak well, the main languages spoken at home in Australia, and the languages they speak the best. Individuals whose best spoken language was not English (generally individuals from non-English speaking countries) had to self-assess their English speaking, reading, and writing skills. Those skills are each categorized into four levels, "Very well", "Well", "Not well", and "Not at all". Similar data were collected from migrating unit spouses.

\section{LANGUAGE SKILLS IN THE FAMILY UNIT}

Table 1 presents information on the distribution of the English speaking skills of the MUS for each level of these skills for the PA. Presentation of these data is informative of the broad patterns of English skills development within the migrating family unit, and it also offers the opportunity to demonstrate the integrity of the data: 
Where a person speaks English only it is expected that the spouse will have at least some English skills. Where a person cannot speak English it is unlikely that their spouse speaks only English. Both patterns are observed in the data.

It is apparent from Table 1 that the distributions across skill levels of PAs and MUSs are quite similar. For example, 1.5 percent of PAs speak English only and 1.8 percent of MUSs speak English only. Similarly, 13 percent of PAs do not speak English at all and 17 percent of MUSs are in this category. Individuals who self-assessed their English speaking skill level as "not well" make up the largest proportion for both PAs (31.3 percent) and also MUSs (38.8 percent).

Within each household, both PA and MUS have very similar language skill levels (as presented in the diagonal cells of the table). For example, 61 percent of PAs who speak English the best have MUSs who also speak English the best. A further 20 percent of the MUSs are in the adjacent English skill categories of "English only" and "very well". In the case of PAs who do not speak English at all, 69 percent of MUSs also do not speak English at all, while a further 26 percent of MUSs speak English "not well".

The zero entries in Table 1 indicate that PAs who speak English only do not have Migrating Unit partners who cannot speak English. Likewise, PAs with poor English skills do not have Migrating Unit partners who speak only English. This makes sense and thus suggests that the data are quite sound.

\section{REGRESSION ESTIMATES}

The binary dependent variable for these analyses has been formed from the categorical data presented in Table 1 by classifying immigrants who speak only English or who speak English the best and those who report another language but speak English either very well or well as proficient in English. Individuals who speak a language other than English the best and speak English either not well or not at all 
are categorized as not proficient in English. Under this definition, the mean rates of proficiency are 54 percent and 44 percent for PAs and MUSs, respectively. ${ }^{13}$

Estimates of the single equation and bivariate probit models outlined above are presented in Table 2. The first two columns of this table list single equation probit estimates for the PAs and their Migrating Unit partners. Both male and female PAs are included in the sample; 79 percent of the PAs are male, 21 percent female. Experiments show that restricting the sample to male PAs has little impact on the findings (see Appendix B), and the pooled approach is adopted for the larger sample it offers and for the insights obtained into the gender differentials in English skills among both PAs and MUSs. The estimates of the bivariate probit model are presented in the final two columns.

The first column of results for PAs are broadly similar to estimates for all immigrants for Australia (and other countries) presented in the literature (e.g., Chiswick and Miller (1995)). These results show a clear hierarchy of English-speaking proficiency by the degree of selectivity of the visa category. Hence, immigrants who entered under a Humanitarian visa (refugees) have the lowest level of English-speaking skills, followed by those who entered under Preferential Family and Concessional Family visas. Immigrants who entered Australia under the main skill-tested categories, either Business Skills or Independent visas, have the highest levels of proficiency in English. In other words, visa category, where points are awarded for English skills in the points-tested categories of Concessional Family, Business Skills and Independent, is an important correlate of the mastery of the English language among recent arrivals. Using the same survey, but considering subsequent waves, Chiswick, Lee and Miller (2000b) show, however, that the influence of visa category on English-speaking skills is short-lived.

The two efficiency variables of age at migration and educational attainment are highly significant. English-speaking proficiency increases with educational attainment, and is greater among those who migrated at an early age. Of the two variables,

\footnotetext{
${ }^{13}$ Variables that by construction of the data are common to both PAs and Spouses are "visit of the PA to Australia prior to migration", "Reasons for chosen State", "ethnic agencies contact", and the family structure variables.
} 
educational attainment appears to be the more important, with each year of education having an impact the equivalent of about immigrating at an age 10 years younger.

The rate of English-speaking proficiency among females is not significantly different from that among males when other variables are the same. The insignificance of the gender effect may be due to the sample for this first set of analyses being restricted to PAs.

There are several birthplace effects that are important, though the most influential of these is for immigration from a former British colony. This result shows that exposure to English prior to migration is a major factor in the model of English skills development. Similarly, individuals who had cross country/culture contact in the former home country and those who visited Australia prior to migration also have relatively high rates of English proficiency. Both variables capture the extent of exposure to English prior to migration.

Individuals for whom family/friends were the main reason for choosing the State of residence have relatively low rates of English proficiency. The presence of family and friends presumably reduces the costs of not being proficient in English; although even at this early period in Australia living among family/friends may have reduced improvement in language skills. As hypothesized above, these factors are expected to also underlie the significant, negative relationship between the degree of proficiency in English and the birthplace concentration variable. The impact of the birthplace concentration variable, where the coefficient is -0.091 and the range of the variable is from 0 to 27, is considerably stronger than that of the "Family/Friends" variable. The birthplace concentration variable captures influences of the immediate (postcode) area of residence, whereas the "Family/Friends" variable does not necessarily have such a narrow geographic focus (other than being restricted to the State of the initial settlement).

There is a non-linear relationship between the physical distance between the country of origin and the capital city of the State in which the immigrant settled. Englishspeaking skills increase with distance up to about 12,000 kilometres, and then decrease. This pattern is inconsistent with the expectation of a monotonic positive 
relationship outlined previously. The reason for this inconsistency appears to be that the greater English skills among immigrants from several of the major origin countries that are furthest from Australia (Western Europe, Northern Europe) are captured by very large country fixed effects. To examine this possibility the equations were re-estimated omitting the country of origin fixed effects. Table 3, which is structured the same as Table 2, lists these estimates. ${ }^{14}$ In this restricted specification the physical distance variables are statistically insignificant. This indicates that the country fixed effects are part of the explanation for the anomalous shape of the relationship between English fluency and the physical distance between the country of origin and Australia. Distance traveled may be a relatively minor component of the total cost of migration, and it may be that other costs components are relatively high for some countries that are in closer geographic proximity to Australia. ${ }^{15}$

The linguistic distance variable is statistically insignificant in these analyses. It was also of minor importance in the study of immigrants to Australia by Chiswick and Miller (1999), whereas it is highly significant in studies of immigrants to the US (see, for example, Chiswick and Miller (1998)). It does become statistically significant with the expected negative sign in the joint probit analyses without the country fixed effects (Table 3). The family structure variables included in the estimating equation are also insignificant. As the sample of PAs is dominated by males (79 percent of the PAs are males) this result is not unexpected.

Examination of the coefficients in the equation estimated for the MUSs reveals that these are in most cases broadly similar to those listed for the PAs. This is especially

\begin{tabular}{lccc}
\hline $\begin{array}{l}14 \\
\text { Deleting the country fixed effects has only a small impact on the equations' prediction success } \\
\text { (percent): }\end{array}$ & $\begin{array}{c}\text { Bivariate } \\
\text { Probit }\end{array}$ \\
\cline { 2 - 4 } & \multicolumn{2}{c}{ Single Equation } & 81.50 \\
Specification & PA & MUS & 79.28 \\
\hline $\begin{array}{l}\text { Includes country fixed } \\
\text { effects (Table 2) }\end{array}$ & 83.63 & 80.30 & \\
$\begin{array}{l}\text { Excludes country fixed } \\
\text { effects (Table 3) }\end{array}$ & 82.61 & 77.98 & \\
\hline
\end{tabular}

15 The Table 3 estimates (excluding country fixed effects) for the other variables are generally quite similar to those reported in Table 2 (incorporating country fixed effects). The remainder of this discussion will be based on the more encompassing models presented in Table 2. 
the case for the behavioral factors such as the birthplace concentration variable and the variable for whether the immigrant visited Australia prior to migration. Accordingly, the discussion will focus on the variables where the estimated coefficients differ for PA and MUS. The first of these is visa category. Only MUSs who entered Australia under a Humanitarian visa have English-speaking skills that are statistically different (at the 5 percent level), that is, lower than the English skills of MUSs who entered Australia under Independent visas. In comparison, visa category has a very strong association with the English-speaking skills of PAs. As the PA was the person upon whom the approval to immigrate was based, the lesser role of visa category in the model of English-speaking skills for MUSs is an intuitively reasonable outcome.

A second variable where the impact differs between PAs and MUSs is age at migration. While this is negative and significant for PAs, it is insignificant for spouses. It could be argued that it is the inclusion of age in the set of characteristics that are eligible for points in the "points-tested" categories for PAs and the absence of such an association with age among MUSs that generates this result. However, there are strong links between age at migration and dominant language skills among immigrants in countries that do not operate points-testing in the issuance of visas (see, for example, Chiswick and Miller's (1992) study of English language proficiency among immigrants in the US and Chiswick (1998) for Israel). Another distinguishing feature of MUSs is that they are likely to be tied movers, and it is factors associated with this status, presumably, which contribute to the different findings for the age at migration variable for MUSs than for other immigrants. For example, tied movers would have a lower expectation of labor market involvement and hence less impact associated with having a longer period over which to reap the benefits from postimmigration investments in human capital, including language capital.

The third variable where there is a significant difference between the results for PAs and MUSs is the "KIDS" variable. Twenty one percent of PAs are female and 79 percent of MUSs are females. As argued in Section II, children are expected to have a more negative impact on the language skills of females than they have on the language skills of males. Children decrease expected female labor supply, and if immigrants learn language in anticipation of labor market payoffs, or they learn it on 
the job (learning by doing), then there will be a more intense negative effect of children on females (disproportionately MUSs) than on males (disproportionately PAs) for whom greater labor supply is anticipated. Moreover, Chiswick and Miller (1994b, p.159) argue that parents can learn English from their children and that children can act as interpreters for their parents. The "children as interpreters" role is suggested to retard English language acquisition and to be more relevant in consumption than in labor market activities. This suggests that there will be a less positive or more negative effect of children on the language fluency for women than for men. Separate analyses (see Appendix B) undertaken for male PAs are strongly consistent with this conjecture. This gender differential in the impact of children on language skills most likely accounts for the difference in the effects of the KIDS variable for PAs and MUSs.

The estimates of the bivariate probit model which takes account of the correlation between the disturbance terms in the language skills equations for PAs and Spouses are associated with few changes in the estimated coefficients for either PAs or MUSs. The correlation coefficient between the disturbance terms in the two models is, however, sizeable and highly significant (coefficient of 0.422 , with a ' $t$ ' of 5.50). The positive value for this coefficient means that in cases where there are unobservables that lead the PA to have greater (lesser) English speaking skills than predicted by the model, then the same or other unobservables will result in the MUS having greater (lesser) English speaking skills than predicted by the model. Assortative mating on the basis of factors that are not included in the model (motivation, ability, even propensity for language skills development), and one spouse learning from the other spouse who is more proficient for unobserved reasons, will generate a positive correlation in the disturbance terms of the models of English speaking proficiency for PAs and the MUSs.

As the correlation coefficient is significant and sizeable, failure to take it into account will result in predictions that are inferior to those obtained with the aid of the bivariate probit model. To illustrate this, several predictions are computed and reported in Table 4. The first two columns of Table 4 present the predicted probabilities of English proficiency from the single equation probit models. The values in the first row are constructed for the value of the probit index that will give the mean rate of 
English proficiency for each sample. The probability that both husband and wife who have these characteristics will be proficient in English is estimated in the third column as the product of the probabilities from the two independent probit models. The assumption implicit in this calculation is that the probabilities are independent. This joint probability is computed to be 23.6 percent. In the final column the joint probability that the representative husband and wife will both be proficient in English is computed from the bivariate probit model. This is estimated to be 31.9 percent. In other words, failure to take account of the correlation between the disturbance terms in the two models would result in an under-prediction in the order of 8.3 percentage points, giving a prediction error of 26 percent.

Several other sets of calculations are listed in Table 4 to illustrate further the advantages of the bivariate probit model. The first two examples are for cases where (i) both PA and MUS have 4 years of education more than the representative immigrant considered above; and (ii) where the PA and MUS both have 4 fewer years of education than the representative immigrant considered above. These cases represent educational attainments approximately one standard deviation above and below the mean for both PAs and MUSs. Comparison of the differences in the predictions for the two levels of education for PAs and MUSs illustrates the greater impact that education has on the language skills of PAs compared to MUSs.

The next two examples are for immigrants where the PA had visited Australia prior to migrating, and for where the PA did not visit. The predictions presented in this instance convey the same story as those presented in relation to educational attainment. This is also the case for the final set of cases presented, namely predictions for where the PA and MUS were both born in a former British colony and for where neither the PA nor the MUS was born in a former British colony.

For each of these three variables, the predictions of the joint probability of both PA and MUS being proficient in English presented in the final two columns of Table 4 is greater in the bivariate probit analysis and the data reveal that the absolute and relative difference in the predictions obtained from the bivariate and single equation probit models is greater at lower levels of the joint probability. This is not surprising 
as at lower levels of independent prediction, there is greater scope for improvement in the joint probabilities.

These results show that the family matters in destination language acquisition. In migrating unit families where the PA has an above average propensity to be proficient in English for unmeasured reasons, the spouse also has an above average propensity to be proficient in English. It is often argued that there is assortative mating on the basis of observable factors such as educational attainment. The findings in this study reveal similarity for migrating unit partners of unobservables that are important to the development of dominant language skills. One of these unobservables may be their learning from each other.

\section{CONCLUSION}

Family matters in the acquisition of dominant language skills. There is a high degree of correlation in the English speaking skills of partners in migrating units among recent immigrants in Australia. For example, 61 percent of Principal Applicants (PAs) who speak English the best have Migrating Unit Spouses (MUSs) who also speak English the best. In the case of PAs who do not speak English at all, 69 percent of MUSs also do not speak English at all, while a further 26 percent of MUSs speak English "not well”.

The model of English speaking skills outlined in this paper provides a basis for explaining the proficiency in English of each migrating unit partner. It links proficiency in English to measurable characteristics such as educational attainment, age at migration, country of birth and visa category. It was shown that the determinants of English-speaking skills were quite similar for PAs and MUSs. This similarity in the structure of the model of English-speaking skills for PAs and MUSs adds to the literature on dominant language skills. The model of dominant language skills applied in this study has previously been shown to be highly robust across destination countries, time periods, countries of origin and legal status. The analyses reported in this study demonstrate that it is also robust with respect to primary and tied-mover status. 
PAs and MUSs have many characteristics in common, with there being a positive correlation between the personal characteristics within migrating units, presumably as a result of assortative mating, and a strong commonality of other demographic characteristics (e.g., birthplace) and institutional characteristics (e.g., visa category) as a result of the migration process. These commonalities combine with the similarity of the processes determining English language skills of PAs and MUS to generate the strong links between the English skills of partners within migrating units.

The model of English-speaking skills estimated for the family suggests there are other factors that need to be considered, and which reinforce the tendency for the Englishspeaking skills of PAs and their spouses to be the same. The disturbance term in the model estimated separately for PAs and MUSs captures the impacts of the range of factors that cannot be measured for inclusion in the model (e.g., motivation, aptitude for the learning of languages). It was found that there is a sizeable positive correlation between the disturbance terms in the models estimated separately for PAs and their migrating unit spouses. This means that in cases where there are unobservables that lead the PA to have greater (lesser) English speaking skills than predicted by the model, then the same or other unobservables will also result in the MUS having greater (lesser) English speaking skills than predicted by the model. It is possible that migrating unit partners learn from each other. Such interactions in the household are important, and are shown to also lead to the differential effects of children on the dominant language skills of PAs and MUSs where the presence of children has little effect on the PAs (primarily males) but a significant negative effect on the MUSs (primarily females). It is certainly the case in the study of dominant language skills that family matters. 
TABLE 1: Principal Applicant's English Speaking Skills by Spouse's English Speaking Skills, 15-64 Year Old Males and Females from Non-English Speaking Countries

\begin{tabular}{|c|c|c|c|c|c|c|c|}
\hline \multirow{2}{*}{$\begin{array}{l}\text { Spouse's } \\
\text { English } \\
\text { Speaking Skill } \\
\text { Level }\end{array}$} & \multicolumn{7}{|c|}{ Principal Applicant's English Speaking Skill Level } \\
\hline & $\begin{array}{l}\text { English } \\
\text { only }\end{array}$ & $\begin{array}{c}\text { English } \\
\text { best }\end{array}$ & $\begin{array}{l}\text { Very } \\
\text { well }\end{array}$ & Well & $\begin{array}{l}\text { Not } \\
\text { well }\end{array}$ & $\begin{array}{l}\text { Not } \\
\text { at all }\end{array}$ & $\begin{array}{c}\% \text { of } \\
\text { Population } \\
(b)\end{array}$ \\
\hline English only & 46.62 & 6.91 & 2.87 & 0.00 & 0.00 & 0.00 & 1.84 \\
\hline English best & 53.38 & 61.30 & 4.97 & 2.55 & 0.25 & 0.00 & 8.42 \\
\hline Very well & 0.00 & 12.92 & 29.92 & 10.41 & 3.80 & 1.39 & 10.45 \\
\hline Well & 0.00 & 10.72 & 41.58 & 40.99 & 10.63 & 3.64 & 23.19 \\
\hline Not well & 0.00 & 7.50 & 18.61 & 37.63 & 67.52 & 25.83 & 38.84 \\
\hline Not at all & 0.00 & 0.65 & 2.05 & 8.41 & 17.81 & 69.14 & 17.25 \\
\hline Total $^{(\mathrm{a}),(\mathrm{b})}$ & 100.00 & 100.00 & 100.00 & 100.00 & 100.00 & 100.00 & 100.00 \\
\hline$\%$ of Population & 1.50 & 9.81 & 16.30 & 28.23 & 31.29 & 12.88 & 100.00 \\
\hline
\end{tabular}


TABLE 2: Bivariate Probit Model of English Speaking Skills, 15-64 Year Old Males and Females from Non-English Speaking Countries, Including Birthplace Fixed Effects

\begin{tabular}{|c|c|c|c|c|}
\hline \multirow[b]{2}{*}{ Variable } & \multicolumn{2}{|c|}{ Single Equation Probit } & \multicolumn{2}{|c|}{ Bivariate Probit } \\
\hline & PA & Spouse & PA & Spouse \\
\hline Constant & $\begin{array}{l}-3.450 \\
(2.89)\end{array}$ & $\begin{array}{l}-4.518 \\
(4.02)\end{array}$ & $\begin{array}{l}-4.232 \\
(2.70)\end{array}$ & $\begin{array}{l}-3.565 \\
(2.65)\end{array}$ \\
\hline $\begin{array}{l}\text { Visa Category } \\
\text { Humanitarian } \\
\text { (Refugee) }\end{array}$ & $\begin{array}{l}-1.341 \\
(6.89)\end{array}$ & $\begin{array}{l}-0.661 \\
(3.78)\end{array}$ & $\begin{array}{l}-1.416 \\
(5.71)\end{array}$ & $\begin{array}{l}-0.675 \\
(3.38)\end{array}$ \\
\hline $\begin{array}{l}\text { Preferential } \\
\text { Family }\end{array}$ & $\begin{array}{l}-0.868 \\
(2.39)\end{array}$ & $\begin{array}{l}-0.558 \\
(1.64)\end{array}$ & $\begin{array}{l}-0.484 \\
(1.36)\end{array}$ & $\begin{array}{l}-0.200 \\
(0.64)\end{array}$ \\
\hline $\begin{array}{l}\text { Concessional } \\
\text { Family }\end{array}$ & $\begin{array}{l}-0.564 \\
(3.55)\end{array}$ & $\begin{array}{l}-0.126 \\
(0.92)\end{array}$ & $\begin{array}{l}-0.500 \\
(2.43)\end{array}$ & $\begin{array}{l}-0.019 \\
(0.12)\end{array}$ \\
\hline $\begin{array}{l}\text { Business } \\
\text { Skills/ENS }\end{array}$ & $\begin{array}{l}-0.256 \\
(1.19)\end{array}$ & $\begin{array}{l}-0.130 \\
(0.73)\end{array}$ & $\begin{array}{l}-0.205 \\
(0.69)\end{array}$ & $\begin{array}{l}-0.118 \\
(0.50)\end{array}$ \\
\hline Age at migration & $\begin{array}{l}-0.021 \\
(3.02)\end{array}$ & $\begin{array}{l}-0.004 \\
(0.51)\end{array}$ & $\begin{array}{l}-0.026 \\
(3.56)\end{array}$ & $\begin{array}{l}-0.008 \\
(0.97)\end{array}$ \\
\hline Education & $\begin{array}{l}0.208 \\
(9.86)\end{array}$ & $\begin{array}{c}0.201 \\
(10.50)\end{array}$ & $\begin{array}{l}0.209 \\
(9.58)\end{array}$ & $\begin{array}{l}0.185 \\
(9.58)\end{array}$ \\
\hline Female & $\begin{array}{l}-0.188 \\
(1.40)\end{array}$ & $\begin{array}{l}-0.084 \\
(0.68)\end{array}$ & $\begin{array}{l}-0.160 \\
(0.92)\end{array}$ & $\begin{array}{l}-0.016 \\
(0.11)\end{array}$ \\
\hline $\begin{array}{l}\text { Birthplace } \\
\text { Western Europe }\end{array}$ & $\begin{array}{c}0.412 \\
(1.05)\end{array}$ & $\begin{array}{l}0.731 \\
(2.36)\end{array}$ & $\begin{array}{l}0.048 \\
(0.08)\end{array}$ & $\begin{array}{l}0.785 \\
(1.98)\end{array}$ \\
\hline Northern Europe & $\begin{array}{l}0.587 \\
(0.93)\end{array}$ & $\begin{array}{l}1.431 \\
(2.74)\end{array}$ & $\begin{array}{l}0.454 \\
(0.51)\end{array}$ & $\begin{array}{l}1.009 \\
(1.92)\end{array}$ \\
\hline Eastern Europe & $\begin{array}{l}-0.852 \\
(3.27)\end{array}$ & $\begin{array}{l}-0.124 \\
(0.50)\end{array}$ & $\begin{array}{l}-1.231 \\
(3.02)\end{array}$ & $\begin{array}{l}-0.424 \\
(1.17)\end{array}$ \\
\hline $\begin{array}{l}\text { The USSR and the } \\
\text { Baltic States }\end{array}$ & $\begin{array}{l}-0.460 \\
(1.95)\end{array}$ & $\begin{array}{l}-0.643 \\
(2.80)\end{array}$ & $\begin{array}{l}-0.639 \\
(2.12)\end{array}$ & $\begin{array}{l}-0.901 \\
(3.44)\end{array}$ \\
\hline The Middle East & $\begin{array}{l}0.394 \\
(1.33)\end{array}$ & $\begin{array}{l}0.581 \\
(2.06)\end{array}$ & $\begin{array}{l}0.349 \\
(0.94)\end{array}$ & $\begin{array}{l}0.396 \\
(1.10)\end{array}$ \\
\hline North Africa & $\begin{array}{l}0.147 \\
(0.40)\end{array}$ & $\begin{array}{l}0.097 \\
(0.27)\end{array}$ & $\begin{array}{l}0.205 \\
(0.47)\end{array}$ & $\begin{array}{l}0.127 \\
(0.30)\end{array}$ \\
\hline South East Asia & $\begin{array}{l}0.458 \\
(0.85)\end{array}$ & $\begin{array}{l}0.861 \\
(1.69)\end{array}$ & $\begin{array}{l}0.989 \\
(1.50)\end{array}$ & $\begin{array}{l}0.293 \\
(0.47)\end{array}$ \\
\hline
\end{tabular}




\begin{tabular}{|c|c|c|c|c|}
\hline North East Asia & $\begin{array}{l}-0.189 \\
(0.37)\end{array}$ & $\begin{array}{l}0.026 \\
(0.05)\end{array}$ & $\begin{array}{l}-0.002 \\
(0.00)\end{array}$ & $\begin{array}{l}-0.282 \\
(0.46)\end{array}$ \\
\hline Southern Asia & $\begin{array}{l}0.174 \\
(0.37)\end{array}$ & $\begin{array}{l}0.274 \\
(0.65)\end{array}$ & $\begin{array}{l}0.411 \\
(0.70)\end{array}$ & $\begin{array}{r}-0.074 \\
(0.16)\end{array}$ \\
\hline $\begin{array}{l}\text { South and Central } \\
\text { America }\end{array}$ & $\begin{array}{l}-0.705 \\
(2.32)\end{array}$ & $\begin{array}{l}-0.080 \\
(0.28)\end{array}$ & $\begin{array}{l}-0.887 \\
(2.10)\end{array}$ & $\begin{array}{l}-0.225 \\
(0.52)\end{array}$ \\
\hline $\begin{array}{l}\text { Former British } \\
\text { colony }\end{array}$ & $\begin{array}{l}1.385 \\
(6.85)\end{array}$ & $\begin{array}{l}1.369 \\
(7.16)\end{array}$ & $\begin{array}{l}1.315 \\
(5.13)\end{array}$ & $\begin{array}{l}1.252 \\
(5.16)\end{array}$ \\
\hline $\begin{array}{l}\text { Cross country/culture } \\
\text { contact in former } \\
\text { home country }\end{array}$ & $\begin{array}{l}0.267 \\
(2.43)\end{array}$ & $\begin{array}{l}0.537 \\
(5.18)\end{array}$ & $\begin{array}{l}0.170 \\
(1.33)\end{array}$ & $\begin{array}{l}0.590 \\
(5.00)\end{array}$ \\
\hline $\begin{array}{l}\text { PA visited } \\
\text { Australia }\end{array}$ & $\begin{array}{l}0.586 \\
(3.88)\end{array}$ & $\begin{array}{l}0.314 \\
(2.39)\end{array}$ & $\begin{array}{l}0.680 \\
(3.33)\end{array}$ & $\begin{array}{l}0.327 \\
(2.11)\end{array}$ \\
\hline $\begin{array}{l}\text { Main reason for } \\
\text { choosing State settled } \\
\text { was Family/Friends }\end{array}$ & $\begin{array}{l}-0.255 \\
(2.04)\end{array}$ & $\begin{array}{l}-0.127 \\
(1.12)\end{array}$ & $\begin{array}{l}-0.294 \\
(2.07)\end{array}$ & $\begin{array}{l}-0.091 \\
(0.76)\end{array}$ \\
\hline $\begin{array}{l}\text { Contact with ethnic } \\
\text { agencies }\end{array}$ & $\begin{array}{c}0.174 \\
(1.48)\end{array}$ & $\begin{array}{l}-0.166 \\
(1.52)\end{array}$ & $\begin{array}{l}0.250 \\
(1.79)\end{array}$ & $\begin{array}{r}-0.150 \\
(1.24)\end{array}$ \\
\hline $\begin{array}{l}\text { Expect to leave } \\
\text { Australia }\end{array}$ & $\begin{array}{l}0.091 \\
(0.28)\end{array}$ & $\begin{array}{l}-0.070 \\
(0.29)\end{array}$ & $\begin{array}{l}-0.413 \\
(1.28)\end{array}$ & $\begin{array}{r}-0.162 \\
(0.40)\end{array}$ \\
\hline $\begin{array}{l}\text { Birthplace } \\
\text { concentration }\end{array}$ & $\begin{array}{l}-0.091 \\
(2.80)\end{array}$ & $\begin{array}{l}-0.064 \\
(2.14)\end{array}$ & $\begin{array}{l}-0.084 \\
(1.63)\end{array}$ & $\begin{array}{l}-0.038 \\
(1.03)\end{array}$ \\
\hline Distance/1000 & $\begin{array}{l}0.362 \\
(2.35)\end{array}$ & $\begin{array}{c}0.241 \\
(1.61)\end{array}$ & $\begin{array}{l}0.477 \\
(2.26)\end{array}$ & $\begin{array}{l}0.216 \\
(1.14)\end{array}$ \\
\hline Distance $^{2} / 1 \mathrm{~m}$. & $\begin{array}{l}-0.015 \\
(2.02)\end{array}$ & $\begin{array}{l}-0.008 \\
(1.13)\end{array}$ & $\begin{array}{l}-0.017 \\
(1.77)\end{array}$ & $\begin{array}{l}-0.009 \\
(1.00)\end{array}$ \\
\hline Linguistic distance & $\begin{array}{l}-0.769 \\
(0.91)\end{array}$ & $\begin{array}{l}-0.418 \\
(0.50)\end{array}$ & $\begin{array}{l}-1.082 \\
(0.89)\end{array}$ & $\begin{array}{r}-0.632 \\
(0.50)\end{array}$ \\
\hline $\begin{array}{l}\text { Family structure } \\
\text { KIDS }^{(\mathrm{b})}\end{array}$ & $\begin{array}{l}-0.120 \\
(0.87)\end{array}$ & $\begin{array}{l}-0.307 \\
(2.47)\end{array}$ & $\begin{array}{l}0.040 \\
(0.25)\end{array}$ & $\begin{array}{r}-0.256 \\
(1.68)\end{array}$ \\
\hline MUR $^{(\mathrm{c})}$ & $\begin{array}{l}-0.139 \\
(0.44)\end{array}$ & $\begin{array}{l}0.039 \\
(0.13)\end{array}$ & $\begin{array}{l}0.272 \\
(0.71)\end{array}$ & $\begin{array}{l}0.488 \\
(1.56)\end{array}$ \\
\hline $\mathrm{OR}^{(\mathrm{d})}$ & $\begin{array}{l}-0.183 \\
(1.25)\end{array}$ & $\begin{array}{l}-0.107 \\
(0.76)\end{array}$ & $\begin{array}{l}-0.030 \\
(0.17)\end{array}$ & $\begin{array}{r}-0.134 \\
(0.82)\end{array}$ \\
\hline$\chi^{2}$ & 706.59 & 572.16 & \multicolumn{2}{|c|}{1022.72} \\
\hline $\begin{array}{l}\text { Prediction success } \\
\text { Rate }(\%)\end{array}$ & 83.63 & 80.30 & \multicolumn{2}{|c|}{81.50} \\
\hline
\end{tabular}


Correlation

Note: Numbers in parentheses are ' $t$ ' statistics.

(a) ENS denotes Employer Nomination Scheme.

(b) Whether children in the household.

(c) Whether other relatives who gained approval to migrate to Australia as part of the Principal Applicant's migration application are present in the household.

(d) Whether other relatives are present in the household.

(e) The total number of cases is 1081 . These data are weighted using sample weights to reflect a population of 12026 .

The benchmark group defined by the omitted categorical variables is immigrants from migrating units that entered Australia under Independent visas, were born in Southern Europe, did not report cross country/culture in the former home country, chose their initial State settled for reasons other than Family/Friends, did not have post-immigration contact with ethnic agencies and do not expect to leave Australia.

Source: Longitudinal Survey of Immigrants to Australia (Wave One) 
TABLE 3: Bivariate Probit Model of English Speaking Skills, 15-64 Year Old Males and Females from Non-English Speaking Countries, Excluding Birthplace Fixed Effects

\begin{tabular}{|c|c|c|c|c|}
\hline \multirow[b]{2}{*}{ Variable } & \multicolumn{2}{|c|}{ Single Equation Probit } & \multicolumn{2}{|c|}{ Bivariate Probit } \\
\hline & PA & Spouse & PA & Spouse \\
\hline Constant & $\begin{array}{l}-2.692 \\
(3.59)\end{array}$ & $\begin{array}{l}-2.514 \\
(3.49)\end{array}$ & $\begin{array}{l}-2.077 \\
(2.44)\end{array}$ & $\begin{array}{l}-2.616 \\
(3.09)\end{array}$ \\
\hline $\begin{array}{l}\text { Visa Category } \\
\text { Humanitarian } \\
\text { (Refugee) }\end{array}$ & $\begin{array}{l}-0.964 \\
(5.82)\end{array}$ & $\begin{array}{l}-0.516 \\
(3.35)\end{array}$ & $\begin{array}{l}-0.957 \\
(5.31)\end{array}$ & $\begin{array}{l}-0.394 \\
(2.59)\end{array}$ \\
\hline $\begin{array}{l}\text { Preferential } \\
\text { Family }\end{array}$ & $\begin{array}{l}-0.757 \\
(2.20)\end{array}$ & $\begin{array}{l}-0.476 \\
(1.45)\end{array}$ & $\begin{array}{l}-0.244 \\
(0.84)\end{array}$ & $\begin{array}{l}-0.025 \\
(0.09)\end{array}$ \\
\hline $\begin{array}{l}\text { Concessional } \\
\text { Family }\end{array}$ & $\begin{array}{l}-0.492 \\
(3.25)\end{array}$ & $\begin{array}{l}-0.047 \\
(0.36)\end{array}$ & $\begin{array}{l}-0.436 \\
(2.36)\end{array}$ & $\begin{array}{l}0.112 \\
(0.77)\end{array}$ \\
\hline $\begin{array}{l}\text { Business } \\
\text { Skills/ENS }\end{array}$ & $\begin{array}{l}-0.293 \\
(1.43)\end{array}$ & $\begin{array}{l}-0.082 \\
(0.48)\end{array}$ & $\begin{array}{l}-0.207 \\
(0.73)\end{array}$ & $\begin{array}{l}-0.018 \\
(0.08)\end{array}$ \\
\hline Age at migration & $\begin{array}{l}-0.023 \\
(3.41)\end{array}$ & $\begin{array}{l}-0.008 \\
(1.20)\end{array}$ & $\begin{array}{l}-0.029 \\
(4.33)\end{array}$ & $\begin{array}{l}-0.013 \\
(1.68)\end{array}$ \\
\hline Education & $\begin{array}{c}0.211 \\
(10.48)\end{array}$ & $\begin{array}{l}0.179 \\
(9.94)\end{array}$ & $\begin{array}{c}0.198 \\
(10.08)\end{array}$ & $\begin{array}{l}0.169 \\
(9.17)\end{array}$ \\
\hline Female & $\begin{array}{l}-0.241 \\
(1.87)\end{array}$ & $\begin{array}{l}-0.080 \\
(0.67)\end{array}$ & $\begin{array}{l}-0.192 \\
(1.19)\end{array}$ & $\begin{array}{r}-0.024 \\
(0.17)\end{array}$ \\
\hline $\begin{array}{l}\text { Former British } \\
\text { colony }\end{array}$ & $\begin{array}{l}1.518 \\
(9.37)\end{array}$ & $\begin{array}{l}1.395 \\
(9.72)\end{array}$ & $\begin{array}{l}1.376 \\
(7.14)\end{array}$ & $\begin{array}{l}1.240 \\
(7.63)\end{array}$ \\
\hline $\begin{array}{l}\text { Cross country/culture } \\
\text { contact in former } \\
\text { home country }\end{array}$ & $\begin{array}{l}0.239 \\
(2.29)\end{array}$ & $\begin{array}{l}0.509 \\
(5.19)\end{array}$ & $\begin{array}{l}0.130 \\
(1.10)\end{array}$ & $\begin{array}{l}0.558 \\
(5.29)\end{array}$ \\
\hline $\begin{array}{l}\text { Previously visited } \\
\text { Australia }\end{array}$ & $\begin{array}{l}0.562 \\
(4.03)\end{array}$ & $\begin{array}{l}0.373 \\
(3.11)\end{array}$ & $\begin{array}{l}0.589 \\
(3.43)\end{array}$ & $\begin{array}{l}0.378 \\
(2.80)\end{array}$ \\
\hline $\begin{array}{l}\text { Main reason for } \\
\text { choosing State settled } \\
\text { was Family/Friends }\end{array}$ & $\begin{array}{l}-0.354 \\
(2.99)\end{array}$ & $\begin{array}{l}-0.207 \\
(1.91)\end{array}$ & $\begin{array}{l}-0.362 \\
(2.72)\end{array}$ & $\begin{array}{l}-0.153 \\
(1.39)\end{array}$ \\
\hline $\begin{array}{l}\text { Contact with ethnic } \\
\text { agencies }\end{array}$ & $\begin{array}{c}0.132 \\
(1.21)\end{array}$ & $\begin{array}{l}-0.161 \\
(1.57)\end{array}$ & $\begin{array}{l}0.217 \\
(1.81)\end{array}$ & $\begin{array}{l}-0.139 \\
(1.25)\end{array}$ \\
\hline $\begin{array}{l}\text { Expect to leave } \\
\text { Australia }\end{array}$ & $\begin{array}{l}0.191 \\
(0.62)\end{array}$ & $\begin{array}{l}-0.002 \\
(0.01)\end{array}$ & $\begin{array}{l}-0.241 \\
(0.75)\end{array}$ & $\begin{array}{l}-0.062 \\
(0.16)\end{array}$ \\
\hline $\begin{array}{l}\text { Birthplace } \\
\text { concentration }\end{array}$ & $\begin{array}{l}-0.095 \\
(2.96)\end{array}$ & $\begin{array}{c}-0.066 \\
(2.14)\end{array}$ & $\begin{array}{l}-0.078 \\
(1.61)\end{array}$ & $\begin{array}{r}-0.042 \\
(1.16)\end{array}$ \\
\hline
\end{tabular}




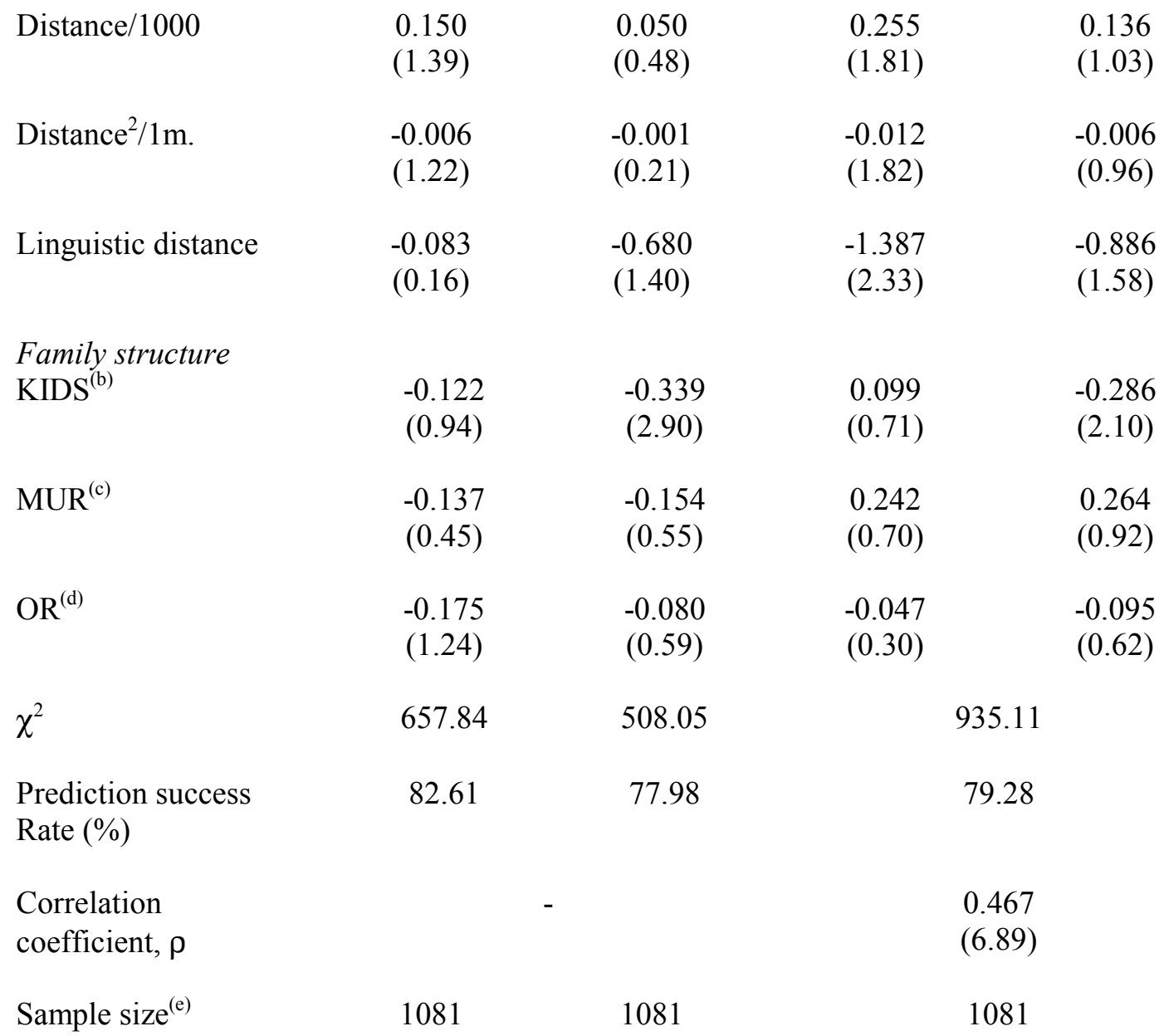

\footnotetext{
Note: Numbers in parentheses are ' $t$ ' statistics.

(a) ENS denotes Employer Nomination Scheme.

${ }^{(b)}$ Whether children in the household.

${ }^{(c)}$ Whether other relatives who gained approval to migrate to Australia as part of the Principal Applicant's migration application are present in the household.

${ }^{(d)}$ Whether other relatives are present in the household.

(e) The total number of cases is 1081. All data are weighted using sample weights to reflect a population of 12026 .
}

The benchmark group defined by the omitted categorical variables is immigrants from migrating units that entered Australia under Independent visas, did not report cross country/culture in the former home country, chose their initial State settled for reasons other than Family/Friends, did not have postimmigration contact with ethnic agencies and do not expect to leave Australia.

Source: Longitudinal Survey of Immigrants to Australia (Wave One) 
TABLE 4: Predicted Probabilities of English Proficiency Obtained from TABLE 2.

\begin{tabular}{|c|c|c|c|c|}
\hline Variable & $\begin{array}{l}\text { Principal } \\
\text { Applicant } \\
\text { (PA) }^{(a)} \\
\text { (i) }\end{array}$ & $\begin{array}{l}\text { Spouse } \\
\text { (ii) }\end{array}$ & $\begin{array}{c}\text { PA* Spouse, } \\
\text { Single Equation } \\
\text { Probit Models }{ }^{(b)} \\
\text { (iii) }\end{array}$ & $\begin{array}{l}\text { PA* Spouse, } \\
\text { Bivariate Probit } \\
\text { Model } \\
\text { (iv) }\end{array}$ \\
\hline $\begin{array}{l}\text { Mean Value of } \\
\text { Variables }\end{array}$ & 54.0 & 43.8 & 23.6 & 31.9 \\
\hline $\begin{array}{l}\text { Mean Years of } \\
\text { Education plus } 4\end{array}$ & 82.5 & 72.1 & 59.5 & 63.6 \\
\hline $\begin{array}{l}\text { Mean Years of } \\
\text { Education minus } 4\end{array}$ & 23.1 & 18.4 & 4.3 & 8.2 \\
\hline $\begin{array}{l}\text { PA Did Not Visit } \\
\text { Australia Prior to } \\
\text { Migration }\end{array}$ & 45.7 & 39.9 & 18.2 & 24.9 \\
\hline $\begin{array}{l}\text { PA Visited Australia } \\
\text { Prior to Migration }\end{array}$ & 71.7 & 52.8 & 37.8 & 43.7 \\
\hline $\begin{array}{l}\text { Not Born in British } \\
\text { Colony }\end{array}$ & 39.3 & 30.6 & 12.0 & 18.0 \\
\hline $\begin{array}{l}\text { Born in British } \\
\text { Colony }\end{array}$ & 85.2 & 77.2 & 65.7 & 69.1 \\
\hline
\end{tabular}

(a) calculated as $\Phi(x \beta)$ from the single equation probit estimates in Table 2.

(b) calculated as the product of the predictions in columns (i) and (ii) under the assumption of independence.

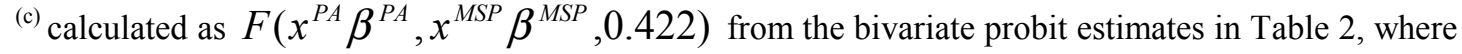
$\mathrm{F}$ is the bivariate standard normal cumulative density function. 


\section{REFERENCES}

Australian Bureau of Statistics (1993). CDATA91 with Mapinfo: 1991 Census of Population and Housing (Australia), Greenwich, New South Wales: Peripheral Systems, Canberra: Australian Bureau of Statistics.

Baker, Michael and Dwayne Benjamin (1997). "The Role of the Family in Immigrants' Labor-Market Activity: An Evaluation of Alternative Explanations", American Economic Review, Vol. 87, No. 4, pp. 705-727.

Beenstock, Michael (1996). "The Acquisition of Language Skills by Immigrants: The Case of Hebrew in Israel”, International Migration, Vol. 34, No. 1, pp. 3-28.

Borjas, George (1992). "Ethnic Capital and Intergenerational Mobility", Quarterly Journal of Economics, Vol. 107, No. 1, pp. 123-150.

Breton, Albert (1978a). Bilingualism: An Economic Approach, Montreal: C.D. Howe Research Institute.

Breton, Albert (1978b). "Nationalism and Language Policies", Canadian Journal of Economics, Vol. 11, No. 4, pp. 656-668.

Chiswick, Barry R. (1977). "Sons of Immigrants: Are They at an Earnings Disadvantage", American Economic Review, Vol. 67, No. 1, pp. 376-380.

Chiswick, Barry R. (1988). "Differences in Education and Earnings Across Racial and Ethnic Groups: Tastes, Discrimination and Investments in Child Quality", Quarterly Journal of Economics, Vol. 103, No. 2, pp. 571-597

Chiswick, Barry R. (1998). "Hebrew Language Usage: Determinants and Effects on Earnings among Immigrants in Israel", Journal of Population Economics, Vol. 11 , No. 2, pp. 253-271.

Chiswick, Barry R. and Paul W. Miller (1992). "Language in the Labor Market: The Immigrant Experience in Canada and the United States", in Barry R. Chiswick (ed.) Immigration, Language and Ethnic Issues: Canada and the United States, Washington, DC: American Enterprise Institute, pp. 229-296.

Chiswick, Barry R. and Paul W. Miller (1994a). "Language Choice Among Immigrants in a Multi-Lingual Destination", Journal of Population Economics, Vol. 7, No. 2, pp. 119-131.

Chiswick, Barry R. and Paul W. Miller (1994b). "Language and Labor Supply: The Role of Gender Among Immigrants in Australia", in D. J. Slottje (ed.) Research on Economic Inequality, Vol.5, pp.153-189.

Chiswick, Barry R. and Paul W. Miller (1995). "The Endogeneity Between Language and Earnings: International Analyses", Journal of Labor Economics, Vol. 13, No. 2, pp. 246-288. 
Chiswick, Barry R. and Paul W. Miller (1996). "Ethnic Networks and Language Proficiency Among Immigrants", Journal of Population Economics, Vol. 9, pp. 19-35.

Chiswick, Barry R. and Paul W. Miller (1998). "English Language Fluency Among Immigrants in the United States", Research in Labor Economics, Vol. 17, pp.151-200.

Chiswick, Barry R. and Paul W. Miller (1999). "Immigration, Language and Multiculturalism in Australia", Australian Economic Review, Vol. 32, No. 4, pp. 369-385.

Chiswick, Barry R. and Paul W. Miller (2001). "A Model of Destination Language Acquisition: Application to Male Immigrants in Canada", Demography, Vol. 38, No. 3, pp. 391-409.

Chiswick, Barry R., Yew Liang Lee and Paul W. Miller (2002a). "Longitudinal Analysis of Immigrant Occupational Mobility: A Test of the Immigrant Assimilation Hypothesis", photocopied, Department of Economics, The University of Western Australia.

Chiswick, Barry R., Yew Liang Lee and Paul W. Miller (2002b). "Immigrants' Language Skills and Visa Category", photocopied, Department of Economics, The University of Western Australia.

Cobb-Clark, Deborah (2001). "The Longitudinal Survey of Immigrants to Australia", Australian Economic Review, Vol. 34, No. 4, pp. 467-477.

Department of Immigration and Multicultural Affairs (DIMA), (1999). Australian Immigration Consolidated Statistics, No. 20, 1997-98. Canberra: DIMA.

Dustmann, Christian (1994). "Speaking Fluency, Writing Fluency and Earnings of Migrants", Journal of Population Economics, Vol. 7, No. 2, pp. 226-236.

Fitzpatrick, Gary L. and Marilyn J. Modlin (1986). Direct-line Distances: International Edition, Metuchen, NJ: The Scarecrow Press Inc.

Hart-Gonzalez, Lucinda and Stephanie Lindemann (1993). "Expected Achievement in Speaking Proficiency, 1993," School of Language Studies, Foreign Services Institute, Department of State, mimeo.

Long, Michael H. (1990). "Maturational Constraints on Language Development", Studies in Second Language Acquisition, Vol. 12, No. 3, pp. 251-285.

Mincer, Jacob (1978). "Family Migration Decisions", Journal of Political Economy, Vol. 86, No.5, pp. 749-773.

Murphy, Jill (1997). Initial Location Decisions of Immigrants, Canberra: Department of Immigration and Multicultural Affairs. 
Service, Elisabet and Fergus I.M. Craik (1993). "Differences Between Young and Older Adults in Learning a Foreign Vocabulary", Journal of Memory and Language, Vol. 32, pp. 608-623. 


\section{APPENDIX A \\ DEFINITIONS OF VARIABLES}

The study is based on the Longitudinal Survey of Immigrants to Australia (LSIA), a sample of Principal Applicant immigrants who arrived in Australia as offshore visaed immigrants in the two-year period of September 1993 to August 1995. The data are from administrative records (for visa category only) and the wave one interviews conducted five to six months after immigration. Spouses who were granted approval to migrate to Australia as part of the Principal Applicants' migration application were also interviewed. The variables used in the statistical analysis are described below. For the statistical analyses, the relevant population is immigrants aged 15-64 years from the countries other than the developed English-speaking countries. These restrictions are applied to both the Principal Applicant and the Migrating Unit Spouse.

\section{Dependent Variable:}

English Speaking Skills: Five levels of English speaking skills are distinguished. They are: (i) English best (or English only); Speaks a language other than English best and speaks English: (ii) Very well; (iii) Well; (iv) Not well; (v) Not at all. In this study the first three categories are denoted "proficient", while the remaining categories are denoted "not proficient".

\section{Independent Variables:}

Age: This is a continuous variable that measures the individual's age. The analysis is restricted to immigrants aged 15 to 64 years.

Educational Attainment: The continuous "Years of Education" variable was created by assigning years of full-time equivalent education to each of the nine levels of education available. They are: (i) Higher degree (19.5 years); (ii) Postgraduate diploma (17.5 years); (iii) Bachelor degree (16.5 years); (iv) Technical/professional qualification (15 years); (v) Trade (13 years) ; (vi) 12 or more years of schooling (13 years); (vii) 10-11 years (10.5 years); (viii) 7-9 years (8 years); and (ix) 6 years or less (6 years).

Gender: Dichotomous variable equal to unity if female.

Birthplace: Fourteen birthplace regions are identified, namely: (i) UK and Ireland; (ii) Southern Europe; (iii) Western Europe; (iv) Northern Europe; (v) Eastern Europe; (vi) The USSR and the Baltic States; (vii) The Middle East; (viii) North Africa; (ix) Southeast Asia; (x) Northeast Asia; (xi) Southern Asia; (xii) North America; (xiii) South and Central America, including Mexico; (xiv) Caribbean, Central and West Africa, and Southern and East Africa. Immigrants from English speaking developed countries (i.e., UK and Ireland, North America and South Africa) are excluded from the analysis. The region of Caribbean, Central and West Africa, and Southern and East Africa has been excluded from the analysis as an insufficient number of immigrants are represented to permit construction of some of the auxiliary regressors employed in the analysis. Note that immigrants from New Zealand are not included 
in the survey. An additional birthplace dichotomous variable is set equal to unity for birthplaces that are former British colonies.

Culture/Country Contact: Dichotomous variable, equal to unity if the immigrant had cross culture/country contact in their former home country.

Visit to Australia: Dichotomous variable equal to unity for those from migrating units where the PA visited Australia prior to migrating.

Reason for Choice of State: Dichotomous variable equal to unity when family and friends were the main reason for choosing the initial State/Territory settled.

Ethnic Agencies Contact: Dichotomous variable equal to unity when the recent arrival had post-immigrant contact with an ethnic organisation, religious organisation, or voluntary welfare agency.

Emigration: Dichotomous variable equal to unity for PAs who expect to return to their former home country or to emigrate to another country.

Birthplace Concentration: The percentage of those in the immigrant's region of residence, measured at the postcode level, born in the same country or region as the immigrant. $^{16}$

Distance: The kilometres between the major city in the immigrant's country of origin and the capital city of the wave one Australian State/Territory of residence. ${ }^{17}$

Language Distance: This variable is constructed from a measure of the difficulty of learning a foreign language for English-speaking Americans. It is based on a set of language scores (LS) measuring achievements in speaking proficiency by Englishspeaking Americans at the U.S. Department of State, School of Language Studies, reported by Hart-Gonzalez and Lindermann (1993). For the same number of weeks of instruction, a lower score (LS) represents less language facility, and, it is assumed, greater linguistic distance between English and the specific foreign language. For example, Italian is scored at 2.5 (in a range from one to three) and Arabic is scored at 1.5. This methodology assumes symmetry across languages, that is, if a language is difficult for English-speaking Americans to learn, it is equally difficult for native speakers of that language to learn English (see Chiswick and Miller (1998)).

Visa Group: Five visa groups are identified in the analysis, and dichotomous variables are used to represent membership of these. They are: (i) Preferential Family; (ii) Concessional Family; (iii) Business Skills and Employer Nomination; (iv) Independent; and (v) Humanitarian. The benchmark group in the regression analysis is Independent.

\footnotetext{
16 The birthplace concentration data are from the 1991 Australian Census of Population and Housing (see Australian Bureau of Statistics (1993)).

${ }^{17}$ These data are from Fitzpatrick and Modlin's (1986) Direct Line Distances, International Edition.
} 
Family Structure: There are three dichotomous variables relating to family structure. They are unity: (i) if there are children in the household (KIDS); (ii) if other relatives who gained approval to migrate to Australia as part of the PA's migration application are present in the household (MUR); and (iii) if other relatives are present in the household (OR).

Table A1: Means and Standard Deviations of Variables, 15-64 Year Old Males and Females from Non-English Speaking Countries

\begin{tabular}{|c|c|c|c|c|c|}
\hline Variable & Mean & $\begin{array}{c}\text { Standard } \\
\text { Deviation }\end{array}$ & Variable & Mean & $\begin{array}{r}\text { Standard } \\
\text { Deviation }\end{array}$ \\
\hline $\begin{array}{l}\text { English } \\
\text { speaking skills }\end{array}$ & 0.489 & 0.497 & $\begin{array}{l}\text { Birthplace } \\
\text { Concentration }\end{array}$ & 1.444 & 2.653 \\
\hline $\begin{array}{l}\text { Age } \\
\text { Educational }\end{array}$ & 36.816 & 8.649 & $\begin{array}{l}\text { Distance ('000) } \\
\text { Ethnic Agencies }\end{array}$ & 11.212 & 3.716 \\
\hline $\begin{array}{l}\text { Attainment } \\
\text { Female }\end{array}$ & $\begin{array}{c}14.477 \\
0.500\end{array}$ & $\begin{array}{l}3.353 \\
0.500\end{array}$ & $\begin{array}{l}\text { Contact } \\
\text { Expect to Leave }\end{array}$ & 0.354 & 0.479 \\
\hline $\begin{array}{l}\text { Birthplace } \\
\text { Western } \\
\text { Europe }\end{array}$ & 0.035 & 0.184 & $\begin{array}{l}\text { Main reason for } \\
\text { choosing State settled } \\
\text { was Family/Friends }\end{array}$ & 0.647 & 0.478 \\
\hline $\begin{array}{l}\text { Northern } \\
\text { Europe } \\
\text { Eastern } \\
\text { Europe } \\
\text { The USSR and } \\
\text { the Baltic } \\
\text { States }\end{array}$ & $\begin{array}{l}0.012 \\
0.059\end{array}$ & $\begin{array}{l}0.109 \\
0.235\end{array}$ & Linguistic Distance & 0.560 & 0.128 \\
\hline $\begin{array}{l}\text { The Middle } \\
\text { East } \\
\text { North Africa }\end{array}$ & $\begin{array}{l}0.099 \\
0.028\end{array}$ & $\begin{array}{l}0.299 \\
0.164\end{array}$ & Humanitarian & 0.268 & 0.443 \\
\hline $\begin{array}{l}\text { South East } \\
\text { Asia } \\
\text { North East }\end{array}$ & 0.168 & 0.374 & $\begin{array}{l}\text { Preferential Family } \\
\text { Concessional } \\
\text { Family } \\
\text { Business }\end{array}$ & 0.296 & $\begin{array}{l}0.184 \\
0.457\end{array}$ \\
\hline $\begin{array}{l}\text { Asia } \\
\text { South Asia }\end{array}$ & $\begin{array}{l}0.174 \\
0.121\end{array}$ & $\begin{array}{l}0.379 \\
0.326\end{array}$ & $\begin{array}{l}\text { Skills/ENS } \\
\text { Independent }\end{array}$ & $\begin{array}{l}0.151 \\
0.250\end{array}$ & $\begin{array}{l}0.358 \\
0.433\end{array}$ \\
\hline $\begin{array}{l}\text { South and } \\
\text { Central } \\
\text { America }\end{array}$ & 0.075 & 0.263 & Family Structure & & \\
\hline $\begin{array}{l}\text { Former British } \\
\text { Colony }\end{array}$ & 0.282 & 0.450 & $\operatorname{KIDS}^{(b)}$ & 0.785 & 0.411 \\
\hline $\begin{array}{l}\text { Culture/Country } \\
\text { Contact }\end{array}$ & 0.604 & 0.489 & $\operatorname{MUR}^{(\mathrm{c})}$ & 0.029 & 0.167 \\
\hline $\begin{array}{l}\text { Visit to } \\
\text { Australia }\end{array}$ & 0.305 & 0.461 & $\mathrm{OR}^{(\mathrm{d})}$ & 0.182 & 0.386 \\
\hline
\end{tabular}


(b) Whether children in the household.

(c) Whether other relatives who gained approval to migrate to Australia as part of the Principal Applicant's migration application are present in the household.

(d) Whether other relatives are present in the household.

(e) Statistics were computed by pooling the MUSs and PAs and getting the averages. The sample size for the Table is therefore 2162 .

Source: Longitudinal Survey of Immigrants to Australia (Wave One) 


\section{APPENDIX B}

\section{ESTIMATES OF BIVARIATE PROBIT MODEL RESTRICTED TO MALE PRINCIPAL APPLICANTS}

Table B1: Bivariate Probit Model of English Speaking Skills, 15-64 Year Old Male Principal Applicants and Female Migrating Unit Spouses from NonEnglish Speaking Countries

\begin{tabular}{|c|c|c|c|c|}
\hline \multirow[b]{2}{*}{ Variable } & \multicolumn{2}{|c|}{ Single Equation Probit } & \multicolumn{2}{|c|}{ Bivariate Probit } \\
\hline & $\mathrm{PA}$ & Spouse & PA & Spouse \\
\hline Constant & $\begin{array}{l}-3.973 \\
(2.56)\end{array}$ & $\begin{array}{l}-3.285 \\
(2.37)\end{array}$ & $\begin{array}{l}-3.793 \\
(2.05)\end{array}$ & $\begin{array}{l}-3.009 \\
(2.03)\end{array}$ \\
\hline $\begin{array}{l}\text { Visa Category } \\
\text { Humanitarian } \\
\text { (Refugee) }\end{array}$ & $\begin{array}{l}-1.475 \\
(6.19)\end{array}$ & $\begin{array}{l}-0.528 \\
(2.41)\end{array}$ & $\begin{array}{l}-1.483 \\
(5.25)\end{array}$ & $\begin{array}{l}-0.577 \\
(2.57)\end{array}$ \\
\hline $\begin{array}{l}\text { Preferential } \\
\text { Family }\end{array}$ & $\begin{array}{l}-0.970 \\
(2.67)\end{array}$ & $\begin{array}{l}0.450 \\
(1.29)\end{array}$ & $\begin{array}{l}-1.035 \\
(2.29)\end{array}$ & $\begin{array}{l}0.463 \\
(1.24)\end{array}$ \\
\hline $\begin{array}{l}\text { Concessional } \\
\text { Family }\end{array}$ & $\begin{array}{l}-0.546 \\
(2.76)\end{array}$ & $\begin{array}{l}-0.034 \\
(0.19)\end{array}$ & $\begin{array}{l}-0.505 \\
(2.15)\end{array}$ & $\begin{array}{l}0.037 \\
(0.21)\end{array}$ \\
\hline $\begin{array}{l}\text { Business } \\
\text { Skills/ENS }\end{array}$ & $\begin{array}{l}-0.312 \\
(1.12)\end{array}$ & $\begin{array}{l}-0.006 \\
(0.03)\end{array}$ & $\begin{array}{l}-0.283 \\
(0.89)\end{array}$ & $\begin{array}{l}-0.034 \\
(0.13)\end{array}$ \\
\hline Age at migration & $\begin{array}{l}-0.021 \\
(2.60)\end{array}$ & $\begin{array}{l}-0.008 \\
(0.95)\end{array}$ & $\begin{array}{l}-0.019 \\
(2.38)\end{array}$ & $\begin{array}{l}-0.011 \\
(1.12)\end{array}$ \\
\hline Education & $\begin{array}{l}0.188 \\
(7.92)\end{array}$ & $\begin{array}{l}0.209 \\
(9.53)\end{array}$ & $\begin{array}{l}0.185 \\
(7.97)\end{array}$ & $\begin{array}{l}0.199 \\
(8.60)\end{array}$ \\
\hline $\begin{array}{l}\text { Birthplace } \\
\text { Western Europe }\end{array}$ & $\begin{array}{l}-0.203 \\
(0.44)\end{array}$ & $\begin{array}{l}0.681 \\
(1.72)\end{array}$ & $\begin{array}{l}-0.126 \\
(0.21)\end{array}$ & $\begin{array}{l}0.640 \\
(1.52)\end{array}$ \\
\hline Northern Europe & $\begin{array}{l}0.397 \\
(0.42)\end{array}$ & $\begin{array}{l}5.409 \\
(0.13)\end{array}$ & $\begin{array}{l}0.396 \\
(0.42)\end{array}$ & $\begin{array}{l}5.409 \\
(0.00)\end{array}$ \\
\hline Eastern Europe & $\begin{array}{l}-1.116 \\
(2.92)\end{array}$ & $\begin{array}{l}-0.367 \\
(1.02)\end{array}$ & $\begin{array}{l}-1.143 \\
(2.48)\end{array}$ & $\begin{array}{l}-0.427 \\
(1.10)\end{array}$ \\
\hline $\begin{array}{l}\text { The USSR and the } \\
\text { Baltic States }\end{array}$ & $\begin{array}{l}-0.453 \\
(1.58)\end{array}$ & $\begin{array}{l}-0.950 \\
(3.20)\end{array}$ & $\begin{array}{l}-0.463 \\
(1.39)\end{array}$ & $\begin{array}{l}-0.922 \\
(3.25)\end{array}$ \\
\hline The Middle East & $\begin{array}{r}0.409 \\
(1.14)\end{array}$ & $\begin{array}{l}0.286 \\
(0.81)\end{array}$ & $\begin{array}{l}0.354 \\
(0.87)\end{array}$ & $\begin{array}{l}0.263 \\
(0.65)\end{array}$ \\
\hline North Africa & $\begin{array}{l}0.468 \\
(0.92)\end{array}$ & $\begin{array}{l}0.006 \\
(0.01)\end{array}$ & $\begin{array}{l}0.394 \\
(0.78)\end{array}$ & $\begin{array}{l}-0.038 \\
(0.08)\end{array}$ \\
\hline
\end{tabular}




\begin{tabular}{|c|c|c|c|c|}
\hline South East Asia & $\begin{array}{l}0.905 \\
(1.36)\end{array}$ & $\begin{array}{l}0.108 \\
(0.17)\end{array}$ & $\begin{array}{l}0.790 \\
(1.01)\end{array}$ & $\begin{array}{l}0.184 \\
(0.27)\end{array}$ \\
\hline North East Asia & $\begin{array}{l}0.118 \\
(0.18)\end{array}$ & $\begin{array}{l}-0.409 \\
(0.67)\end{array}$ & $\begin{array}{l}-0.064 \\
(0.09)\end{array}$ & $\begin{array}{l}-0.341 \\
(0.52)\end{array}$ \\
\hline Southern Asia & $\begin{array}{l}0.531 \\
(0.92)\end{array}$ & $\begin{array}{l}-0.314 \\
(0.61)\end{array}$ & $\begin{array}{l}0.486 \\
(0.72)\end{array}$ & $\begin{array}{l}-0.218 \\
(0.42)\end{array}$ \\
\hline $\begin{array}{l}\text { South and Central } \\
\text { America }\end{array}$ & $\begin{array}{l}-0.842 \\
(1.86)\end{array}$ & $\begin{array}{l}-0.195 \\
(0.43)\end{array}$ & $\begin{array}{l}-0.831 \\
(1.74)\end{array}$ & $\begin{array}{l}-0.310 \\
(0.62)\end{array}$ \\
\hline $\begin{array}{l}\text { Former British } \\
\text { colony }\end{array}$ & $\begin{array}{l}1.361 \\
(5.46)\end{array}$ & $\begin{array}{l}1.409 \\
(6.03)\end{array}$ & $\begin{array}{l}1.302 \\
(4.42)\end{array}$ & $\begin{array}{l}1.269 \\
(4.58)\end{array}$ \\
\hline $\begin{array}{l}\text { Cross country/culture } \\
\text { contact in former } \\
\text { home country }\end{array}$ & $\begin{array}{l}0.139 \\
(1.09)\end{array}$ & $\begin{array}{l}0.673 \\
(5.54)\end{array}$ & $\begin{array}{l}0.111 \\
(0.80)\end{array}$ & $\begin{array}{l}0.616 \\
(4.53)\end{array}$ \\
\hline $\begin{array}{l}\text { PA visited } \\
\text { Australia }\end{array}$ & $\begin{array}{l}0.754 \\
(4.09)\end{array}$ & $\begin{array}{l}0.183 \\
(1.16)\end{array}$ & $\begin{array}{l}0.714 \\
(3.17)\end{array}$ & $\begin{array}{l}0.174 \\
(1.02)\end{array}$ \\
\hline $\begin{array}{l}\text { Main reason for } \\
\text { choosing State settled } \\
\text { was Family/Friends }\end{array}$ & $\begin{array}{l}-0.274 \\
(1.95)\end{array}$ & $\begin{array}{l}-0.183 \\
(1.44)\end{array}$ & $\begin{array}{l}-0.268 \\
(1.73)\end{array}$ & $\begin{array}{l}-0.182 \\
(1.36)\end{array}$ \\
\hline $\begin{array}{l}\text { Contact with ethnic } \\
\text { agencies }\end{array}$ & $\begin{array}{l}0.211 \\
(1.54)\end{array}$ & $\begin{array}{l}-0.239 \\
(1.86)\end{array}$ & $\begin{array}{l}0.217 \\
(1.40)\end{array}$ & $\begin{array}{r}-0.227 \\
(1.66)\end{array}$ \\
\hline $\begin{array}{l}\text { Expect to leave } \\
\text { Australia }\end{array}$ & $\begin{array}{l}-0.479 \\
(1.41)\end{array}$ & $\begin{array}{l}-0.174 \\
(0.64)\end{array}$ & $\begin{array}{l}-0.348 \\
(1.05)\end{array}$ & $\begin{array}{l}-0.124 \\
(0.28)\end{array}$ \\
\hline $\begin{array}{l}\text { Birthplace } \\
\text { concentration }\end{array}$ & $\begin{array}{l}-0.057 \\
(1.66)\end{array}$ & $\begin{array}{l}-0.043 \\
(1.37)\end{array}$ & $\begin{array}{l}-0.052 \\
(0.93)\end{array}$ & $\begin{array}{l}-0.047 \\
(1.16)\end{array}$ \\
\hline Distance/1000 & $\begin{array}{l}0.358 \\
(1.70)\end{array}$ & $\begin{array}{l}0.146 \\
(0.71)\end{array}$ & $\begin{array}{l}0.307 \\
(1.31)\end{array}$ & $\begin{array}{l}0.142 \\
(0.67)\end{array}$ \\
\hline Distance $^{2} / 1 \mathrm{~m}$ & $\begin{array}{l}-0.010 \\
(1.01)\end{array}$ & $\begin{array}{l}-0.006 \\
(0.60)\end{array}$ & $\begin{array}{l}-0.008 \\
(0.74)\end{array}$ & $\begin{array}{l}-0.006 \\
(0.56)\end{array}$ \\
\hline Linguistic distance & $\begin{array}{l}-0.799 \\
(0.74)\end{array}$ & $\begin{array}{l}-0.916 \\
(0.85)\end{array}$ & $\begin{array}{l}-0.400 \\
(0.28)\end{array}$ & $\begin{array}{l}-0.806 \\
(0.58)\end{array}$ \\
\hline $\begin{array}{l}\text { Family structure } \\
\text { KIDS }^{(\mathrm{b})}\end{array}$ & $\begin{array}{l}0.012 \\
(0.08)\end{array}$ & $\begin{array}{l}-0.369 \\
(2.46)\end{array}$ & $\begin{array}{l}-0.018 \\
(0.10)\end{array}$ & $\begin{array}{r}-0.405 \\
(2.31)\end{array}$ \\
\hline MUR $^{(\mathrm{c})}$ & $\begin{array}{c}0.125 \\
(0.34)\end{array}$ & $\begin{array}{c}0.548 \\
(1.66)\end{array}$ & $\begin{array}{l}0.222 \\
(0.51)\end{array}$ & $\begin{array}{c}0.513 \\
(1.41)\end{array}$ \\
\hline $\mathrm{OR}^{(\mathrm{d})}$ & $\begin{array}{c}-0.049 \\
(0.28)\end{array}$ & $\begin{array}{l}0.050 \\
(0.29)\end{array}$ & $\begin{array}{l}-0.064 \\
(0.33)\end{array}$ & $\begin{array}{c}0.031 \\
(0.16)\end{array}$ \\
\hline
\end{tabular}


$\begin{array}{llll}\text { Prediction success } & 83.16 & 79.06 & 78.36\end{array}$

Rate $(\%)$

Correlation

coefficient, $\rho$

Sample size ${ }^{(e)}$

855

855

855

Note: Numbers in parentheses are ' $t$ ' statistics.

(a) ENS denotes Employer Nomination Scheme.

(b) Whether children in the household.

${ }^{\text {(c) }}$ Whether other relatives who gained approval to migrate to Australia as part of the Principal Applicant's migration application are present in the household.

(d) Whether other relatives are present in the household.

(e) The total number of cases is 855 . These data are weighted using sample weights to reflect a population of 9613

The benchmark group defined by the omitted categorical variables is immigrants from migrating units that entered Australia under Independent visas, were born in Southern Europe, did not report cross country/culture in the former home country, chose their initial State settled for reasons other than Family/Friends, did not have post-immigration contact with ethnic agencies and do not expect to leave Australia.

Source: Longitudinal Survey of Immigrants to Australia (wave one) 


\section{IZA Discussion Papers}

No.

Author(s)

R. Lalive

J. Zweimüller

G. S. Epstein

446

E. Yashiv

447

M. Fertig

C. M. Schmidt

M. P. Keane

E. S. Prasad

B. R. Chiswick

P. W. Miller

B. R. Chiswick

Y. L. Lee

P. W. Miller

M. Lindeboom

M. Kerkhofs

M. Galeotti

L. J. Maccini

F. Schiantarelli
Title

Area

Date

Benefit Entitlement and the Labor Market:

02/02

Evidence from a Large-Scale Policy Change

Informational Cascades and Decision to Migrate 1

Macroeconomic Policy Lessons of Labor Market 6

$03 / 02$

Frictions

Mobility within Europe - What do we (still not)

know?

Inequality, Transfers and Growth: New Evidence 4

from the Economic Transition in Poland

Do Enclaves Matter in Immigrant Adjustment? $\quad 1$

$03 / 02$

Schooling, Literacy, Numeracy and Labor

03/02

Market Success

The Complementarity of Language and Other

Human Capital: Immigrant Earnings in Canada

Longitudinal Analysis of Immigrant Occupational $\quad 1$

Mobility: A Test of the Immigrant Assimilation

Hypothesis

Removing the Veil of Ignorance in Assessing the 6

Distributional Impacts of Social Policies

03/02

Defensive Innovations

03/02

Unions and Establishment Performance:

Evidence from the British Workplace Industrial/

Employee Relations Surveys

International Integration, Risk and the Welfare 2

03/02

State

Health and Work of the Elderly: Subjective

3

03/02

Health Measures, Reporting Errors and the Endogenous Relationship between Health and Work

Inventories, Employment and Hours

5

03/02

The Covariance Structure of East and West

3

03/02 German Incomes and its Implications for the Persistence of Poverty and Inequality

Family Matters: The Role of the Family in 2

Y. Liang Lee

P. W. Miller

Immigrants' Destination Language Acquisition

An updated list of IZA Discussion Papers is available on the center's homepage www.iza.org. 